\title{
DESKRIPSI KETERAMPILAN DASAR LABORATORIUM MAHASISWA TEKNIK PADA PRAKTIKUM KIMIA DASAR
}

\author{
Eliyart \& Chichi Rahayu* \\ Fakultas Teknik dan Perencanaan, Universitas Ekasakti Padang \\ *Corresponding Author: rahayuchichi@gmail.com
}

\section{Article History}

Received : March 04 $4^{\text {th }}, 2021$

Revised : March $15^{\text {th }}, 2021$

Accepted : April 28 $8^{\text {th }}, 2021$

Published : May 05 ${ }^{\text {th }}, 2021$

\begin{abstract}
Abstrak: Penelitian ini dilatarbelakangi rendahnya hasil rata-rata nilai ujian praktikum kimia dasar mahasiswa teknik. Pelaksanaan perkuliahan kimia dasar tidak terlepas dari kegiatan praktikum. Praktikum mempunyai peranan yang krusial untuk mendukung kualitas hasil dan proses pembelajaran. Kegiatan praktikum dapat meningkatkan keahlian mahasiswa dalam pengamatan, keterampilan/aspek psikomotorik serta sebagai sarana berlatih menggunakan alat dan bahan yang ada di laboratorium. Tujuan penelitian ini untuk mendeskripsikan keterampilan dasar laboratorium mahasiswa teknik pada praktikum kimia dasar. Jenis penelitian ini deksriptif kuantitatif. Populasi penelitian merupakan mahasiswa tingkat I Fakultas Teknik dan Perencanaan Universitas Ekasakti dalam perkuliahan Kimia Dasar semester ganjil 2020/2021. Instrumen penelitian menggunakan lembar observasi (pengamatan). Penilaian lembar pengamatan keterampilan dasar mengacu pada rubrik penskoran. Rubrik penskoran berisi kriteria penilaian langkah-langkah kerja sistematis yang harus dilakukan mahasiswa saat praktikum. Berdasarkan hasil analisis data diperoleh keterampilan dasar laboratorium mahasiswa teknik sebagai berikut; mengambil bahan dengan persentase $80 \%$ menunjukan kriteria baik, menggunakan alat dengan persentase $60,5 \%$ menujukan kriteria cukup, mengamati dengan persentase $67,75 \%$ menunjukan kriteria cukup, mengkomunikasikan dengan persentase $73,25 \%$ menunjukan kriteria cukup, dan keselamatan kerja dengan persentase $75,75 \%$ menunjukan kriteria baik. Secara keseluruhan keterampilan dasar laboratorium mahasiswa teknik berada pada kriteria cukup. Diharapkan pada praktikum semester berikutnya mahasiswa lebih termotivasi untuk mengikuti kegiatan praktikum, serta dosen dan instruktur membimbing mereka dengan memberikan pembelajaran sains yang menyenangkan dan inovatif.
\end{abstract}

Kata Kunci: praktikum, kimia dasar, keterampilan dasar laboratorium

\section{PENDAHULUAN}

Bidang pendidikan memegang peranan penting dan strategis sebab merupakan sebuah wahana untuk meningkatkan kualitas sumber daya manusia (Zakirman, 2017). Peningkatan kualitas sumber daya manusia melalui jalur pendidikan mulai dari pendidikan dasar dan menengah hingga pendidikan tinggi adalah kunci untuk dapat mengikuti perkembangan global (Putri, Ulhusna, Zakirman, \& Gusta, 2020). Pendidikan di perguruan tinggi menjembatani societal needs, industrial needs, professional needs dan keunggulan bangsa (Asmaningrum, Koirudin, \& Kamariah, 2018) . Oleh karena itu, tuntutan pendidikan yang sangat besar mendorong para pendidik dan peserta didik untuk dapat berperan serta dalam berbagai perkembangan di dunia pendidikan (Zakirman \& Hidayati, 2017). Saat ini misi dalam melaksanakan pendidikan berubah dari menciptakan lulusan hanya untuk siap kerja di dunia industri, menjadi lulusan yang siap untuk menghadapi pekerjaan yang mengutamakan kemampuan berfikir tingkat tinggi yang disebut keterampilan bekerja ilmiah (Fitriani, 2017).

Keterampilan bekerja ilmiah merupakan keterampilan untuk melakukan metode ilmiah dalam menemukan suatu konsep sains dan mengembangkannya (Khoiriroh \& Shofiyah, 2019). Gagne dalam Herni (2017) mengidentifikasi keterampilan ilmiah yang dibagi menjadi dua kelompok besar, yaitu keterampilan dasar dan keterampilan terintegrasi (Pujiastutik, 2017). Praktikum merupakan suatu aktivitas yang dapat digunakan untuk melatih 
keterampilan dasar (Bastin \& Dicks, 2019). Pelaksanaan kegiatan praktikum mempunyai peranan yang sangat krusial untuk mendukung kualitas hasil dan proses pembelajaran karena kegiatan praktikum akan lebih efektif untuk meningkatkan keahlian mahasiswa dalam pengamatan dan meningkatkan keterampilan/aspek psikomotorik serta sebagai sarana berlatih dalam menggunakan atupun memanfaatkan alat dan bahan yang ada di laboratorium (Wahyudiati, 2016). Keterampilan dasar yang dapat teramati selama praktikum diantaranya; (1) mengambil bahan, (2) menggunakan alat, (3) mengamati, (4) mengkomunikasikan, (5) keselamatan kerja (Kartini, 2018).

Secara etimologi kata "laboratorium" berasal dari kata latin yang berarti "tempat bekerja" dan dalam perkembangannya kata "laboratorium" mempertahankan arti aslinya yaitu "tempat bekerja", akan tetapi khusus untuk keperluan penelitian ilmiah (Muna, 2016). Pemanfaatan laboratorium untuk kegiatan pratikum merupakan bagian dari proses belajar mengajar (Mamlok-Naaman \& Barnea, 2012). Melalui kegiatan praktikum, mahasiswa dapat membuktikan konsep atau teori yang sudah ada dan dapat mengalami proses atau percobaan itu sendiri, kemudian mengambil kesimpulan, sehingga dapat menunjang pemahaman mahasiswa terhadap materi kuliah. Dalam hal ini, jika mahasiswa lebih paham terhadap materi kuliah diharapkan hasil belajarnya dapat meningkat (Eliyarti, Rahayu, \& Zakirman, 2020). Pemanfaatan laboratorium sangat penting dalam pendidikan kimia. Jika kita ingin siswa kita tahu apa dan bagaimana ahli kimia lain (cendekiawan sains) lakukan dan melibatkan mereka dalam kesenangan sains, kita harus dapat membiarkan mereka mempraktikkan aktivitas proses sains seperti observasi, pengukuran, perbandingan, klasifikasi, dan evaluasi (Geleta, 2015).

Mata kuliah kimia dasar merupakan mata kuliah dasar untuk mempelajari ilmu kimia di tingkat perguruan tinggi. Kimia dasar juga merupakan salah satu mata kuliah yang memuat banyak konsep dan studi praktikum (Asmaningrum et al., 2018). Kegiatan pembelajaran di perguruan tinggi melibatkan mahasiswa secara aktif (student centered). Dosen harus mampu melaksanakan pembelajaran dengan berorientasi pada kegiatan mahasiswa dalam menemukan dan menetapkan makna secara mandiri (Eliyarti \& Rahayu, 2019a). Agar konsep-konsep kimia dapat dipahami oleh mahasiswa maka pembelajaran kimia di perguruan tinggi juga menekankan pada pemberian pengalaman belajar secara langsung melalui penggunaan dan pengembangan keterampilan proses dan sikap serta bisa memanfaatkan bahan yang ada di lingkungan sekitar yang mendukung pada proses pembelajaran (Olubu, 2015). Penelitian terdahulu yang dilakukan oleh Riswanto (2017) menunjukan bahwa sebanyak $85,71 \%$ siswa telah memiliki keterampilan ilmiah dengan skor $\geq 71$ melalui pembelajran berbasis laboratorium (Riswanto \& Dewi, 2017). Hilda Weny (2016) juga melakukan penelitian dengan hasil persentase rata-rata keseluruhan sikap psikomotor mahasiswa $63.88 \%$ melalui kegiatan praktikum (Jayanti, Sartika, \& Kurniawan, 2016).

Praktikum Kimia Dasar di Fakultas Teknik Universitas Ekasakti terdiri dari 8 percobaan yaitu; (1) reaksi-reaksi kimia, (2) perubahan kimia dan perubahan Fisika, (3) Koloid, (4) kesetimbangan kimia, (5) kinematika reaksi, (6) reaksi redoks, (7) logam alkali, (8) logam alkali tanah. Praktikum kimia dasar wajib diikuti oleh semua mahasiswa Teknik Tahun I. Namun, kegiatan praktikum dalam perkuliahan kimia dasar di FT Unes masih belum maksimal. Hal ini dapat dilihat dari rata-rata nilai ujian praktikum secara klasikal adalah 68 dengan persentase mahasiswa yang lulus $40,34 \%$ dan yang tidak lulus $59,66 \%$. Sebagai solusi dari permasalahan tersebut maka dilakukan penelitian dengan tujuan mendeskripsikan keterampilan dasar laboratorium mahasiswa teknik pada praktikum kimia dasar. Aspek keterampilan dasar yang difokuskan dalam penelitian ini meliputi keterampilan: a) Mengambil bahan, b) Menggunakan alat praktikum c) Mengamati, Mengkomunikasikan hasil praktikum, dan e) keselamatan kerja.

\section{METODE}

Jenis penelitian ini adalah deksriptif kuantitatif yang bertujuan untuk mendeskripsikan keterampilan dasar laboratorium mahasiswa teknik pada praktikum kimia dasar. Populasi penelitian ini adalah mahasiswa tingkat I Fakultas Teknik dan Perencanaan Universitas Ekasakti dalam perkuliahan Kimia Dasar semester ganjil 2020/2021, dengan sample penelitian berjumlah 80 orang yang dipilih dengan teknik simple 
random sampling. Teknik pengumpul data yang digunakan adalah teknik nontes berupa lembar observasi. Lembar observasi digunakan untuk memperoleh data perilaku yang dilakukan mahasiswa selama kegiatan praktikum berlangsung. Pengamatan dilakukan oleh tiga orang observer.

Prosedur penelitian yang dilakukan adalah: (1) penyusunan lembar pengamatan, (2) pelaksanaan praktikum (3) analisa lembar pengamatan, (4) menarik kesimpulan. Penilaian lembar pengamatan keterampilan dasar ini mengacu pada rubrik penskoran. Rubrik penskoran berisi kriteria penilaian langkahlangkah kerja sistematis yang harus dilakukan mahasiswa saat praktikum. Rubrik penskoran dapat dilihat pada Tabel 1 dibawah ini.

Tabel 1 Rubrik keterampilan dasar laboratorium mahasiswa teknik

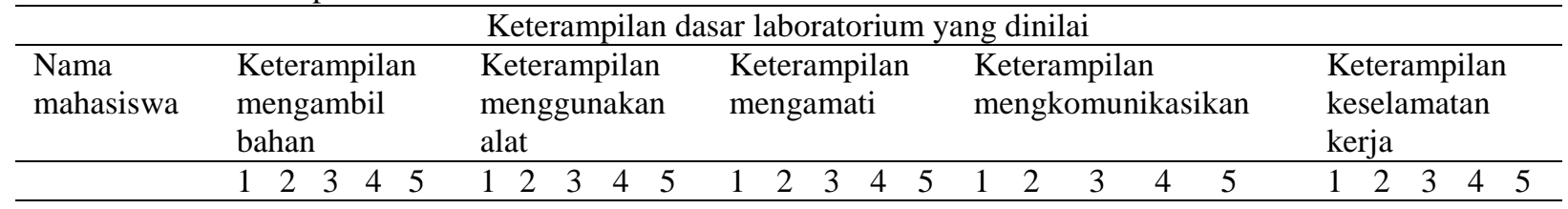

Skala penilaian dibuat dengan bobot 1 sampai 5 sesuai tingkat ketepatan dalam melakukan keterampilan dasar laboratorium saat praktikum. Penafsiran untuk skala penilaian disajikan pada tabel dibawah ini.

Tabel 2. Penafsiran untuk skala penilaian keterampilan kerja ilmiah

\begin{tabular}{ll}
\hline Bobot & Penafsiran \\
\hline 5 & kriteria sangat tepat \\
\hline 4 & kriteria tepat \\
\hline 3 & kriteria kurang tepat \\
\hline 2 & kriteria tidak tepat \\
\hline 1 & kriteria sangat tidak tepat \\
\hline
\end{tabular}

Data keterampilan dasar laboratorium mahasiswa selanjutnya akan diklasifikasi berdasarkan perolehan persentase sesuai dengan Tabel 3 berikut.

Tabel 3. Klasifikasi Perolehan Persentase

\begin{tabular}{lll}
\hline No & Perolehan persentase & Keterangan \\
\hline 1 & $86 \leq \mathrm{N} \leq 100$ & Sangat baik \\
\hline 2 & $76 \leq \mathrm{N} \leq 85$ & Baik \\
\hline 3 & $60 \leq \mathrm{N} \leq 75$ & Cukup \\
\hline 4 & $55 \leq \mathrm{N} \leq 59$ & Kurang \\
\hline 5 & $0 \leq \mathrm{N} \leq 54$ & Kurang sekali \\
\hline (Purwanto, 2010$)$ &
\end{tabular}

\section{HASIL DAN PEMBAHASAN}

Praktikum kimia dasar dilaksanakan sebanyak 8 kali praktek pada 80 mahasiswa untuk memperoleh data keterampilan dasar praktikum. Selanjutnya dianalisis sehingga didapatkan nilai rata-rata dan persentase pada masing-masing kriteria keterampilan dasar yang diteliti. Berikut hasil dan pembahasan yang diperoleh;

a. Mengambil bahan

Sebelum praktikum dimulai instruktur telah menyediakan berbagai bahan kimia di meja utama. Selanjutnya masing-masing kelompok diminta untuk mengambil bahan yang diperlukan dan meletakannya dalam baki pembawa bahan. Penilaian pada kriteria ini meliputi mampu menentukan jenis bahan yang diperlukan sesuai dengan tujuan praktikum, mengetahui sifat zat dan wujudnya (apakah zat berbahaya, mudah terbakar, beracun, mudah menguap, dan lainnya), membaca label yang tertera pada botol dengan baik, dan terampil mengambil bahan cair tanpa tercecer. Mahasiswa yang tidak terampil dalam mengambil bahan melakukan berbagai kesalahan diantaranya volume cairan yang diambil kurang dari yang seharusnya, memasukan kembali bahan yang tersisa ke dalam botol zat murni sehingga dapat merusak zat, dan lainnya.

Berdasarkan hasil pengamatan diperoleh data mahasiswa dalam mengambil bahan dengan kriteria sangat tepat sebanyak 20 orang, kriteria tepat sebanyak 45 orang, kriteria kurang tepat sebanyak 10 orang, dan kriteria tidak tepat sebanyak 5 orang. Setelah dinalisis dari skor yang diperoleh pada masing-masing kriteria didapatkan total skor 320, dalam persentase diperoleh hasil $80 \%$. Secara umum hasil analisis kriteria mengambil bahan dapat disajikan berupa grafik seperti berikut ini. 


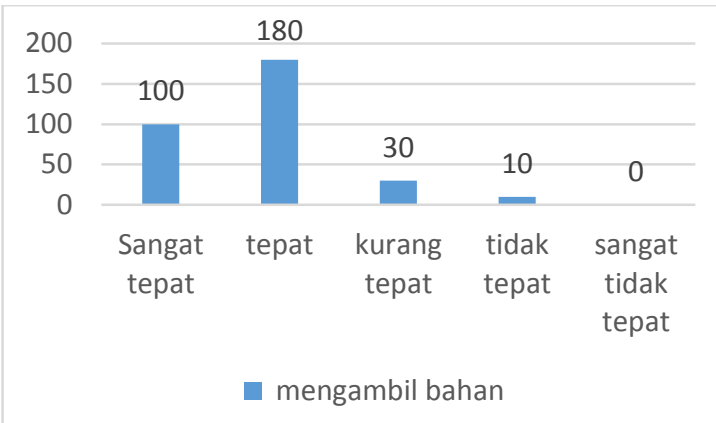

Gambar 1. Grafik Hasil Analisis Kriteria Terampil Mengambil Bahan

b. Menggunakan Alat

Saat praktikum mahasiswa diharuskan mampu menggunakan alat-alat labor dengan baik. Dalam menggunakan alat mahasiswa dituntut untuk berhati-hati, tidak terburu-buru, tenang dan berkonsentrasi. Penilaian pada kriteria ini meliputi; mengetahui alat yang tepat untuk mengambil bahan yang akan digunakan, menggunakan alat dengan benar, dan mencuci alat setelah digunakan. Penggunaan alat praktikum yang tidak sesuai dengan petunjuk akan mempengaruhi hasil praktikum. Mahasiswa yang tidak berkonsentrasi saat menggunakan alat praktikum sering kali menunjukan kesalahan kerja misalnya salah menempatkan tabung reaksi saat pemanasan, tidak menutup kembali botol zat setelah zat diambil, tidak menggunakan kertas saring saat melakukan penyaringan, dan lainnya.

Berdasarkan hasil pengamatan diperoleh data mahasiswa yang menggunakan alat dengan kriteria sangat tepat sebanyak 8 orang, kriteria tepat sebanyak 20 orang, kriteria kurang tepat sebanyak 30 orang, kriteria tidak tepat sebanyak 30 orang, dan kriteria sangat tidak tepat 12 orang. Setelah dinalisis dari skor yang diperoleh pada masing-masing kriteria didapatkan total skor adalah 242 , dalam persentase diperoleh hasil $60,5 \%$. Secara umum hasil analisis kriteria menggunakan alat dapat disajikan berupa grafik seperti berikut ini.

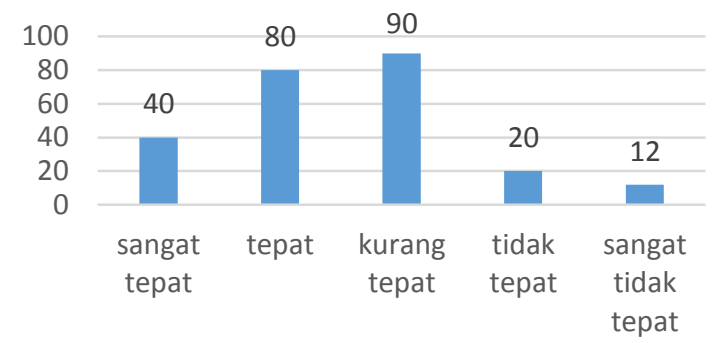

menggunakan alat

Gambar 2. Grafik Hasil Analisis Kriteria Menggunakan Alat

c. Mengamati

Pembelajaran berkaitan dengan bagaimana meningkatkan rasa ingin tahu mahasiswa. Rasa ingin tahu dapat ditumbuhkan atau dihilangkan sangat tergantung bagaimana pembelajaran dilakukan (Zakirman, Lufri, Khairani, \& Rahayu, 2020b). Keterampilan mengamati ditunjukan dengan rasa ingin tahu yang tinggi. Penilaian pada kriteria ini meliputi; mengikuti praktikum dengan antusias, memperhatikan fenomena reaksi yang terjadi selama praktikum, serta mencatat pengamatan dengan baik.

Berdasarkan data yang diperoleh mahasiswa yang menunjukan keterampilan mengamati dengan kriteria sangat tepat sebanyak 18 orang, kriteria tepat sebanyak 22 orang, kriteria kurang tepat sebanyak 20 orang, kriteria tidak tepat sebanyak 13 orang, dan kriteria sangat tidak tepat sebanyak 7 orang. Setelah dinalisis dari skor yang diperoleh pada masing-masing kriteria didapatkan total skor adalah 271, dalam persentase diperoleh hasil $67,75 \%$. Secara umum hasil analisis kriteria mengamati dapat disajikan berupa grafik seperti berikut ini.

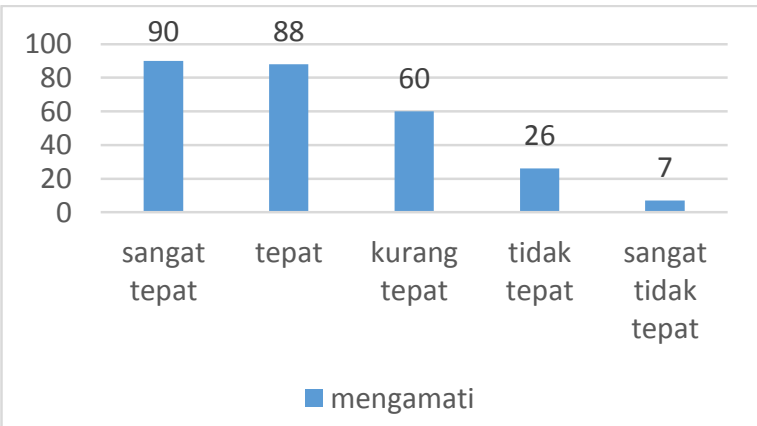

Gambar 3. Grafik Hasil Analisis Kriteria Mengamati

d. Mengkomunikasikan

Setelah mahasiswa melakukan kegiatan praktikum, mereka diminta untuk melakukan persentasi. Kegiatan ini efektif untuk melatih 
mahasiswa dalam mengkomunikasikan hasil pengamatannya. Komunikasi yang efektif dapat dikatakan saling bertukar informasi dan ide antara dua orang atau lebih yang hasilnya sesuai dengan harapan (Zakirman \& Rahayu, 2018). Komunikasi yang baik saat persentasi dapat menghindari miskonsepsi atas hasil praktikum. Penilaian pada kriteria ini meliputi; pemahaman konsep materi kimia dasar yang dipraktikumkan, mampu membaca data hasil praktikum, menyampaikan hasil yang diperoleh dengan baik, mampu menjawab pertanyaan dari mahasiswa lainnya yang bertanya. Dapat diamati saat persentasi masih ada mahasiswa yang tidak mampu mengkomunikasikan hasil praktikumnya dengan baik serta cenderung ragu-ragu dalam penyampaian.

Berdasarkan hasil pengamatan diperoleh data mahasiswa dengan kriteria sangat tepat sebanyak 25 orang, kriteria tepat sebanyak 20 orang, kriteria kurang tepat sebanyak 23 orang, kriteria tidak tepat sebanyak 9 orang, dan kriteria sangat tidak tepat sebanyak 5 orang. Setelah dinalisis dari skor yang diperoleh pada masingmasing kriteria didapatkan total skor adalah 293, dalam persentase diperoleh hasil 73,25\%. Secara umum hasil analisis kriteria mengkomunikasikan dapat disajikan berupa grafik seperti berikut ini.

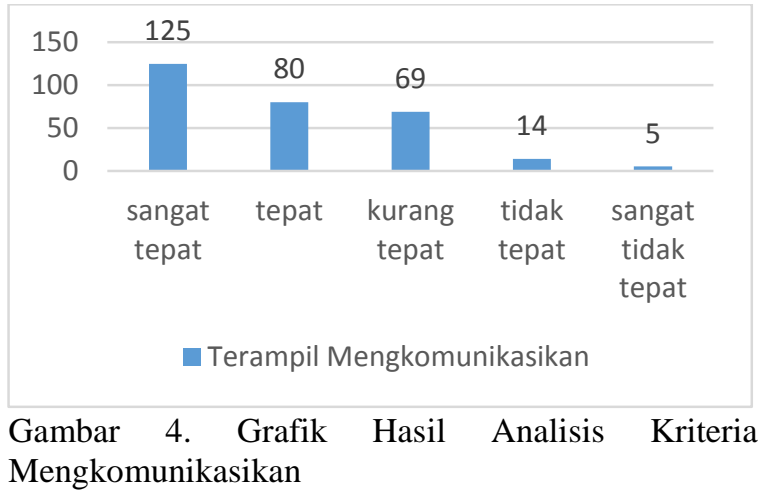

\section{e. Keselamatan Kerja}

Keselamatan kerja penting dalam kegiatan praktikum. Keselamatan kerja di laboratorium berisikan tata tertib selama berada di laboratorium (Supriyadi \& Lismawati, 2018). Keselamatan kerja merupakan upaya preventif dan represif terhadap kecelakaan yang merupakan akibat atas desain, sistem, proses serta kegiatan di laboratorium. Mahasiswa yang memiliki keterampilan keselamatan kerja menunjukan sikap patuh, berhati-hati, dan disiplin. Penilaian dalam keselamatan kerja selama praktikum yaitu menggunakan jas lab dan sepatu tertutup, penempatan alat aman (di atas meja agak ke tengah), serta disiplin bekerja. Dalam menggunakan dan meletakkan alat sudah baik dalam artian tidak membahayakan praktikan.

Berdasarkan hasil pengamatan diperoleh data mahasiswa yang memiliki keterampilan keselamatan kerja dengan kriteria sangat tepat sebanyak 25 orang, kriteria tepat sebanyak 20 orang, kriteria kurang tepat sebanyak 23 orang, kriteria tidak tepat sebanyak 9 orang, dan kriteria sangat tidak tepat sebanyak 5 orang. Setelah dinalisis dari skor yang diperoleh pada masingmasing kriteria didapatkan total skor adalah 293, dalam persentase diperoleh hasil 73,25\%. Secara umum hasil analisis kriteria keselamatan kerja dapat disajikan berupa grafik seperti berikut ini.

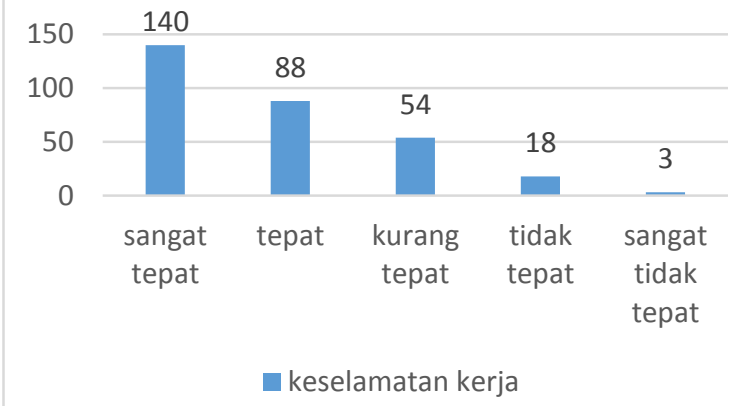

Gambar 5. Grafik Hasil Analisis Keriteria Keselamatan Kerja

Secara keseluruhan peresentase hasil analisis keterampilan kerja ilmiah mahasiswa pada materi kesetimbangan kimia dapat dinyatakan sebagai berikut.

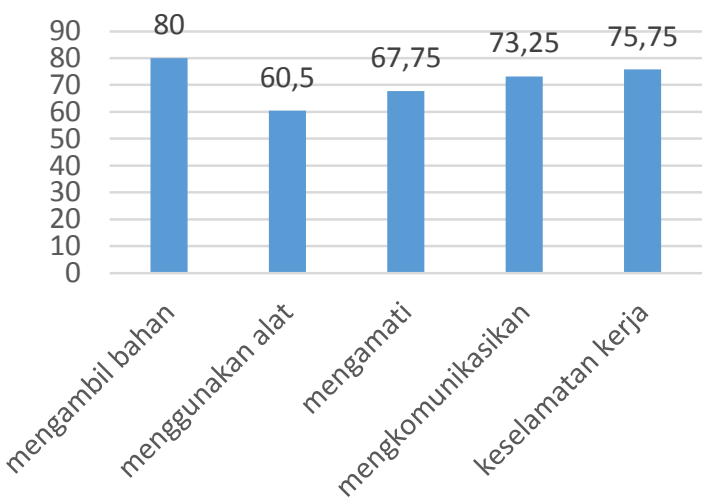

keterampilan dasar laboratorium mahasiswa

Gambar 6. Grafik Persentase Hasil Analisis Keterampilan Dasar Laboratorium Mahasiswa Teknik

Berdasarkan hasil analisis keterampilan dasar laboratorium mahasiswa teknik diperoleh persentase sebagai berikut; mengambil bahan dengan persentase $80 \%$ menunjukan kriteria baik, menggunakan alat dengan persentase 60,5\% 
menujukan kriteria cukup, mengamati dengan persentase $67,75 \%$ menunjukan kriteria cukup, mengkomunikasikan dengan persentase $73,25 \%$ menunjukan kriteria cukup, dan keselamatan kerja dengan persentase $75,75 \%$ menunjukan kriteria baik. Secara keseluruhan keterampilan dasar laboratorium mahasiswa teknik berada pada kriteria cukup. Hal ini terjadi karena kurangnya kesungguhan mahasiswa dimana beberapa terlihat sering bercanda dengan mahasiswa lainnya saat praktek berlangsung dan kurang memperhatikan tata cara pemakaian alat. Keterampilan dasar mengambil bahan, mengkomunikasikan, serta keselamatan kerja menunjukan hasil yang lebih baik pada praktek ke -4 dan seterusnya. Setelah praktek ke-4 mahasiswa mulai menunjukan sikap disiplin dan mengikuti prosedur praktikum dengan baik.

Upaya peningkatan hasil belajar mahasiswa melalui pembelajaran di laboratorium dapat efektif jika dibarengi dengan motivasi belajar dari mahasiswa (Suleiman Abdulrahman \& Hui, 2018). Motivasi belajar sangat berpengaruh terhadap prestasi belajar yang diukur dari hasil belajar mahasiswa (Harefa \& Silalahi, 2020). Hal ini menunjukan bahawa proses pembelajaran dapat diimbangi dengan proses ilmiah. Ini diyakini sebagai jalan untuk pengembangan sikap, keterampilan, dan pengetahuan peserta didik (Zakirman, Lufri, Khairani, \& Rahayu, 2020a). Seseorang yang memiliki motivasi berprestasi tinggi akan menunjukan sikap: 1) memiliki tanggung jawab yang tinggi pada tugasnya, 2) menetapkan tujuan yang menantang, sulit dan realistik, 3) memiliki harapan sukses, 4) melakukan usaha yang keras untuk mencapai kesuksesan, 5) tidak memikirkan kegagalan, dan 6) berusaha memperoleh hasil yang terbaik (Eliyarti \& Rahayu, 2019b).

\section{KESIMPULAN}

Hasil analisis keterampilan dasar laboratorium mahasiswa teknik diperoleh persentase sebagai berikut; mengambil bahan dengan persentase $80 \%$ menunjukan kriteria baik, menggunakan alat dengan persentase 60,5\% menujukan kriteria cukup, mengamati dengan persentase $67,75 \%$ menunjukan kriteria cukup, mengkomunikasikan dengan persentase $73,25 \%$ menunjukan kriteria cukup, dan keselamatan kerja dengan persentase $75,75 \%$ menunjukan kriteria baik. Secara keseluruhan keterampilan dasar laboratorium mahasiswa teknik berada pada kriteria cukup. Diharapkan pada praktikum semester berikutnya mahasiswa lebih termotivasi untuk mengikuti kegiatan praktikum, serta dosen dan instruktur membimbing mereka dengan memberikan pembelajaran sains yang menyenangkan dan inovatif.

\section{TERIMA KASIH}

Penulis mengucapkan terima kasih kepada pihak-pihak yang membantu kelancaran terlaksananya penelitian ini diantaranya K.a Laboratorium Dasar Universitas Ekasakti Padang serta rekanrekan dosen yang menjadi observer.

\section{DAFTAR PUSTAKA}

Asmaningrum, H. P., Koirudin, I., \& Kamariah. (2018). Pengembangan Panduan Praktikum Kimia Dasar Terintegrasi Etnokimia Untuk Mahasiswa. Jurnal Tadris Kimiya, 2(Desember), 125-134.

Bastin, L. D., \& Dicks, A. P. (2019). Advances in green chemistry education. Green Chemistry Letters and Reviews, 8253(May). https://doi.org/10.1080/17518253.2019.16 $\underline{21059}$

Eliyarti, E., \& Rahayu, C. (2019a). Deskripsi Efektivitas Kegiatan Praktikum Dalam Perkuliahan Kimia Dasar Mahasiswa Teknik. Edu Sains: Jurnal Pendidikan Sains \& Matematika, 7(2), 51-60.

Eliyarti, E., \& Rahayu, C. (2019b). Tinjauan Motivasi Berprestasi Mahasiswa Teknik Dalam Perkuliahan Kimia Dasar. Jurnal Pendidikan Glasser, 3(2), 196-204.

Eliyarti, E., Rahayu, C., \& Zakirman, Z. (2020). Deskripsi Pengetahuan Awal Alat Praktikum Materi Koloid Dalam Perkuliahan Kimia Dasar Mahasiswa Teknik. Dalton; Jurnal Pendidikan Kimia Dan Ilmu Kimia, 3(1), 14-25.

Fitriani, R. (2017). Perbedaan Kemampuan Dasar Bekerja Ilmiah Mahasiswa Biologi Yang Menggunakan Model Pembelajaran Inkuiri dan Group Investigation. Bioedusiana, 02(01), 109-116.

Geleta, T. (2015). How Can I Improve My 
Students' Ability In Doing Laboratory Practical Work On Analytical ChemistryI? A Case On Class N23 At KCTE. AJCE, 5(January), 13-43.

Harefa, N., \& Silalahi, N. F. D. (2020). Improvement of Student 's Learning Outcomes and Motivation With Chemical Practicum e-Module. Jurnal Pendidikan Kimia, 12(1), 10-19. https://doi.org/10.24114/jpkim.v12i1.1770 $\underline{8}$

Jayanti, H. W., Sartika, R. P., \& Kurniawan, R. A. (2016). Analisis Kemampuan Psikomotorik Mahasiswa Semester III Program Studi Pendidikan Kimia Universitas Muhammadiyah Pontianak. Ar-Razi Jurnal Lmiah, 4(2), 62-72.

Kartini, K. S. (2018). Deskripsi Perkembangan Keterampilan Dasar Kerja Laboratorium Kimia Siswa Sma Negeri 1 Singaraja. Hydrogen: Jurnal Kependidikan Kimia, 6(1), 21-31.

Khoiriroh, F., \& Shofiyah, N. (2019). Perbedaan Keterampilan Proses Sains Siswa Kelas VII Pada Penggunaan Laboratorium Riil Dengan Laboratorium Virtual di SMP Negeri 1 Candi. Proceedings of the ICECRS, 2(1), 299-305. https://doi.org/10.21070/picecrs.v2i1.2388

Mamlok-Naaman, R., \& Barnea, N. (2012). Laboratory Activities in Israel. Eurasia Journal of Mathematics, Science \& Technology Education, 8(1), 49-57. https://doi.org/10.12973/eurasia.2012.816 a

Muna, I. A. (2016). Optimalisasi Fungsi Laboratorium IPA Melalui Kegiatan Praktikum Pada Prodi PGMI Jurusan Tarbiyah STAIN Ponorogo. Kodifikasia, 10(1), 109-131.

Olubu, O. M. (2015). Influence of Laboratory Learning Environment on Students' Academic Performance in Secondary School Chemistry. US-China Education Review A, 5(12), 814-821. https://doi.org/10.17265/2161$\underline{623 X / 2015.12 .005}$
Pujiastutik, H. (2017). Analisis Keterampilan Dasar Mahasiswa Calon Guru Biologi pada Mata Kuliah Pengenalan Laboratorium Biologi UNIROW Tuban. Proceeding Biology Education Conference, 14, 565-571.

Purwanto, N. (2010). Prinsip-Prinsip dan Teknik Evaluasi Pengajaran. Jakarta: Rosda.

Putri, S. D., Ulhusna, M., Zakirman, Z., \& Gusta, W. (2020). Improvement of Student Science Literacy Skills Through EdmodoBased Teaching Materials in Learning Science in Elementary School. International Journal of Scientific \& Technology Research (IJSTR), 9(03), 4649-4652.

Riswanto, R., \& Dewi, A. K. (2017). Peningkatan Keterampilan Proses Sains Melalui Pembelajaran Berbasis Laboratorium Untuk Mewujudkan Pembelajaran Berkarakter. JRKPF, 4(2), 60-65.

Suleiman Abdulrahman, A., \& Hui, X. (2018). Implication of Motivation Theories on Teachers Performance in the Context of Education System in Tanzania. International Journal of Secondary Education, $\quad 6(3), \quad 46$. https://doi.org/10.11648/j.ijsedu.2018060 $\underline{3.11}$

Supriyadi, S., \& Lismawati, I. (2018). Pra Praktikum: Pengembangan Ensiklopedia Alat-alat Laboratorium Biologi di SMP/MTs. JOBE, Journal of Biology Education, 1(1), 81-92.

Wahyudiati, D. (2016). Analisis Efektivitas Kegiatan Praktikum Sebagai Upaya Peningkatan Hasil Belajar Mahasiswa. Jurnal Tatsqif, 14(2), 143-168. https://doi.org/10.20414/jtq.v14i2.27

Zakirman, \& Rahayu, C. (2018). Popularitas WhatsApp Sebagai Media Komunikasi dan Berbagi Informasi Akademik Mahasiswa. Perpustakaan Arsip Dan Dokumentasi, 10(1), 27-38. https://doi.org/10.15548/shaut.v10i1.7

Zakirman, Z. (2017). Pengelompokkan gaya belajar mahasiswa menurut teori honey mumford berdasarkan intensitas 
kunjungan pustaka. Ristekdik, 4(1), 1-6.

Zakirman, Z., \& Hidayati, H. (2017). Praktikalitas Media Video dan Animasi Dalam Pembelajaran Fisika di SMP. Jurnal Ilmiah Pendidikan Fisika Al-Biruni, 06(April), 85-93. https://doi.org/10.24042/jpifalbiruni.v6i1. $\underline{592}$

Zakirman, Z., Lufri, L., Khairani, K., \& Rahayu, C. (2020a). Implementation of The PlayThink-Pair-Share (PTPS) Learning Model for Elementary School Students to Master
Part of Top Skill 2020. International Journal of Scientific \& Technology Research (IJSTR), 9(03), 4643-4648.

Zakirman, Z., Lufri, L., Khairani, K., \& Rahayu, C. (2020b). The effect of using play-thinkpair-share ( PTPS ) model to improve student learning outcomes in magnet topic for elementary school. IOP Conference Series: Journal of Physics, 1481, 0-11. https://doi.org/10.1088/1742$\underline{6596 / 1481 / 1 / 012078}$ 